Niepełnosprawność. Dyskursy pedagogiki specjalnej

\title{
O możliwościach i ograniczeniach wsparcia w dorosłości osób z głębszą niepełnosprawnością intelektualną. Refleksje na temat budowania lokalnego systemu wsparcia dorosłych osób z niepełnosprawnością w Gdańsku
}

\section{On possibilities and limitations in support of adult people with moderate and severe intellectual disabilities. Reflexions on the local support system for adults with disabilities in Gdańsk}

\begin{abstract}
Adulthood of people with moderate and severe intellectual disability requires a special support in many spheres and in various environments. The adulthood appears not only the result of the condition of a particular person with intellectual disability, but also is a derivative of some offers dedicated for people with disabilities. The article aims to present some local proposals/offers for people with intellectual disabilities, particularly connected with establishing some more adequate/accurate support system network for this group of people.
\end{abstract}

Słowa kluczowe: dorosłość, niepełnosprawność intelektualna, system wsparcia, lokalne rozwiązania Keywords: adulthood, intellectual disability, local support system and its offe

\section{Wprowadzenie}

Dorosłość osób z głębszą niepełnosprawnością intelektualną wymaga niewątpliwie wsparcia w wielu zakresach i w różnych środowiskach życia. To jaka ona jest bywa nie tylko wynikiem samych możliwości osoby niepełnosprawnej intelektualnie, ale również rozwiązań adresowanych do tej grupy osób. Artykuł pokazuje pewne lokalne rozwiązania dedykowane osobom z niepełnosprawnością intelektualną związane z budowaniem/„uzdrowieniem” pewnego systemu wsparcia tej grupy osób. 


\section{Specyficzna czy zupełnie inna dorosłość?}

Dorosłość osób z głębszą niepełnosprawnością intelektualną jawi się jako konstrukt na pozór łatwy do zdefiniowania, bo mający swój punkt zakorzenienia w dorosłości jako takiej. Często jest to jednak „inna”, specyficzna dorosłość. Niewątpliwie jest to wynik samej specyfiki niepełnosprawności intelektualnej, ale również jest to wynik funkcji relacji danej osoby z otoczeniem.

Najczęściej ta dorosłość charakteryzowana bywa przez pryzmat wyzwań związanych ze wspieraniem danej osoby w "byciu dorosłym”. Paradoksalnie ta dorosłość w przeróżnych narracjach jest często swoistą (nie)dorosłością - akcentuje się w nich bowiem ograniczenia jednostki, ale podaje również sposoby wsparcia w wielu zakresach stanowiących o „byciu dorosłym”. Trudno wyobrazić sobie przestrzeń własnej dorosłości tak bardzo uwikłaną w niemożność i ograniczenia.

Według B. Tylewskiej-Nowak (2011, s. 19) dorosłość osób niepełnosprawnych intelektualnie próbuje się charakteryzować przede wszystkim porównując z dorosłością osób w normie, przy czym „porównania te zawsze wskazują różnice i skupiają się na odmiennościach widocznych w funkcjonowaniu dorosłych osób z obydwu grup oraz barierach stojących przed osobami z niepełnosprawnością, których one same często nie są w stanie pokonać". Wątpliwości budzić może ten swoistego rodzaju punkt odniesienia, jakim jest dorosłość każdego człowieka, ale rzecz raczej w potrzebach i pragnieniach pojedynczego człowieka, jego dążeniu jako gwarancji realizacji tego co jest nam potrzebne lub czego pragniemy. B. Tylewska-Nowak proponuje następującą definicję dorosłości osób z głębszą niepełnosprawnością intelektualną: „to osoby, które ukończyły 18 rok życia, zakonczyły edukację szkolną i próbują funkcjonować w rolach społecznych charakterystycznych dla okresu dorosłości. Powinny one mieć sformułowaną wizję własnej dorosłości z uwzględnieniem wszelkich możliwości i ograniczeń. W formułowaniu tej wizji nie można pominąć roli środowiska, które pomaga lub przeszkadza w jej budowaniu" (2011, s. 22). Tak więc można na ową dorosłość spojrzeć w kontekście prób podejmowanych przez jednostkę i jej (jakby) eksperymentowania w zakresie własnych możliwości bycia samodzielnym i niezależnym.

Zdaniem L. Bakiery, Ż. Steller: „aby osoby z niepełnosprawnością intelektualną mogły realizować siebie na miarę swoich możliwości, bez poczucia odrzucenia czy wyobcowania, nie wystarczy idea integracji i akceptacja społeczna" (2010, s. 151). Według autorek potrzebna jest praca nastawiona na budowanie autonomii i samoświadomość osób z niepełnosprawnością intelektualną. Niewątpliwie jednak wyzwanie dotyczące wspierania w niezależności nie jest tylko wyzwaniem dla profesjonalistów, ale przede wszystkim dla rodziców czy tez opiekunów. Wiele problemów i konfliktów dotyczy relacji w triadzie: osoba wspomagana/rodzice 
/ profesjonalista. Wydaje się, że jednym z poważniejszych wyzwań jest tu brak uzgodnionej wspólnej wizji dorosłości osoby wspieranej. Oczywiście można obwiniać rodziców czy opiekunów za brak dobrej woli, ograniczanie możliwości „bycia dorosłym” przez swoje dorosłe dziecko z niepełnosprawnością intelektualną, ale istotną kwestią jest też to, iż wielu rodziców ma niejasną wizję dorosłości swoich dzieci „naznaczoną” jeszcze lękiem i nieprzewidywalnością.

Jak podkreśla A. Żyta: „wielu rodziców dorosłych osób z niepełnosprawnością intelektualną nie widzi szans na ich niezależne życie, samodzielne zamieszkanie, możliwość utrzymania się z własnych dochodów, możliwość decydowania o swoim losie czy założenia własnej rodziny. Nie zawsze wiąże się to z rzeczywistym poziomem możliwości ich dorosłych dzieci" (2012, s. 152).

Zdaniem A. Szalast również „w obliczu dorosłości przeżywanej w warunkach niepełnej sprawności intelektualnej mamy do czynienia z tymi samymi zadaniami rozwojowymi, tymi samymi emocjami, tymi samymi lękami oraz dodatkowo z licznymi utrudnieniami, mającymi swe źródło w stereotypowo osadzonym funkcjonowaniu środowiska społecznego, często nie gotowego na przyjęcie dorosłej osoby z niepełnosprawnością intelektualną i/lub psychiczną" (2012, s. 148).

W ciekawy sposób o tej dorosłości wypowiada się A. Zawiślak: „W opisie ich funkcjonowania w okresie dorosłości należy przyjąć założenie o ich równouprawnieniu.(...) konsekwencją będzie przypisywanie im normalnych ról społecznych, które są pełnione przez wszystkich ludzi. Zakładać musimy, zgodnie ze współczesnymi podejściami społecznymi, że środowisko społeczne musi niejako wychodzić naprzeciw tym osobom, dawać prawa do osiągania dorosłości oraz jednocześnie pomagać w tym procesie. Nie znaczy to, że każda z tych osób będzie $\mathrm{w}$ stanie funkcjonować na najwyższym poziomie $\mathrm{w}$ tym zakresie. Będą istniały ograniczenia wynikające z właściwości biopsychospołecznych tych osób. Odpowiedź na pytanie o możliwości autonomicznego funkcjonowania $\mathrm{w}$ wieku dorosłym osób z niepełnosprawnością intelektualną powinna być pozytywna, jednak samostanowienie należy rozumieć na miarę tych osób. W praktyce więc będą różne oblicza autonomii, tak różne jak różne są te osoby" (2008, s. 59).

Zdaniem D. Wolskiej osoba z niepełnosprawnością intelektualną w biegu życia jest $\mathrm{w}$ stanie wypracować $\mathrm{w}$ sobie umiejętności będące pewnymi dyspozycjami osobowościowymi świadczącymi o dorosłości jak np. niezależność do pełnienia roli społecznej, pogodę ducha i spokój wewnętrzny, poczucie wewnętrznej siły i możliwości oddziaływania na innych, otwartość na doświadczenie życiowe innych i otaczającą rzeczywistość, uznanie wzajemnej zależności jako esencji bytu ludzkiego, umiejętność cieszenia się cudzą radością, umiejętność pełnego przeżywania chwili, wiara w siebie i innych czy też działanie w pełni spontaniczne, „pod warunkiem, że środowisko pozwoli jej na to i podejmie się przygotowania jej do pełnienia ról społecznych w dorosłym życiu" (2011, s. 45). Istotną kwestią jest więc 
to, jakie znaczenia osoby wspierające osobę z niepełnosprawnością intelektualną nadają wsparciu w dorosłości, bowiem od tych znaczeń zależy owe "pozwalanie”.

A. Żyta wymienia szereg barier, jakie znajdują się "na drodze ku aktywnej, autonomicznej i satysfakcjonującej dorosłości" (2009, s. 83) Dotyczą one według autorki zarówno ograniczeń wewnętrznych, które wiążą się z poziomem funkcjonowania osoby niepełnosprawnej intelektualnie, jak i barier zewnętrznych, które tkwią w środowisku rodzinnym czy społecznym (wraz z systemem wsparcia). Autorka wspomina również o tym, że zjawisko automarginalizacji i bierności osób niepełnosprawnych, przy braku odpowiednich kompetencji, braku aspiracji i ograniczaniu autonomii ze strony najbliższych (rodziców, opiekunów) prowadzić może do niewykorzystywania swojego potencjału, a w efekcie do wtórnego upośledzenia (tamże, s. 84).

\section{Wspieranie w dorosłości osób z głębsza niepełnosprawnością intelektualną - bariery i wyzwania}

Jakże, jeszcze do niedawna, gorzko brzmiał fragment raportu: „Sprawiedliwość, prawa i integracja osób niepełnosprawnych intelektualnie" dotyczącego sytuacji osób z niepełnosprawnością intelektualną w Polsce, zrealizowanego przez Inclusion Europe: „Tylko najbiedniejsza warstwa polskiego społeczeństwa ma prawo do bezpłatnych świadczeń, wszyscy inni muszą za nie płacić. Jednakże większości osób niepełnosprawnych nie stać na nie i dlatego nie korzystają ze świadczeń oraz usług.

Generalnie rzecz ujmując, w Polsce jest niewiele świadczeń i usług dla tej grupy, przede wszystkim ze względu na brak funduszy. Osoby z niepełnosprawnością intelektualną nie są chronione od ubóstwa w żaden sposób. Ich społeczne zasiłki są na poziomie socjalnego minimum. Istnieje różnica między integracyjnymi i zinstytucjonalizowanymi placówkami: placówki integracyjne są prowadzone $\mathrm{w}$ zasadzie przez organizacje pozarządowe, od których osoby z niepełnosprawnością intelektualną otrzymują pomoc w przystosowaniu się do normalnego życia. Instytucjonalne placówki w dalszym ciągu prowadzone są na podstawie przestarzałego modelu opieki całkowitej, co powoduje wstrzymywanie procesu wszelkiej integracji. Nie ma w Polsce koordynacji usług świadczonych na podstawie różnych przepisów prawnych. Osoby korzystające ze świadczeń i usług muszą samodzielnie zdobyć niezbędne informacje na temat przeznaczonych dla nich świadczeń i usług. Generalnie rzecz biorąc, informacje o nich oraz o ich jakości są niewystarczające. Istnieje niewiele świadczeń i usług, przez co wybór między nimi jest bardzo ograniczony. Zainteresowani mogą jednak złożyć skargę na złą jakość usług do odpowiednich władz. System świadczeń i usług nie gwarantu- 
je integracji, przestrzegania zakazu dyskryminacji oraz równego uczestnictwa osób z niepełnosprawnością intelektualną w życiu społecznym. System usług jest bardzo mały, nieelastyczny i bardzo rzadko świadczona jest pomoc $w$ celu zapewnienia integracji oraz niezależności osób niepełnosprawnych" (Sprawiedliwość, prawa i integracja osób niepełnosprawnych intelektualnie, s. 18).

Oceniając działania z zakresu polityki społecznej odnoszące się do wspierania osób z niepełnosprawnością intelektualną w ich dorosłości zwraca uwagę przede wszystkim „brak usystematyzowanej i rzetelnej informacji oraz uporządkowanych danych statystycznych na temat sytuacji osób z niepełnosprawnością intelektualną. Większość dostępnych danych bądź traktuje osoby z niepełnosprawnością jak jednorodną grupę, bądź grupuje informacje na temat osób z niepełnosprawnością intelektualną razem z osobami z problemami zdrowia psychicznego i innymi rodzajami niepełnosprawności” (Raport: „Prawa osób z niepełnosprawnością intelektualna. Dostęp do edukacji i zatrudnienia" 2006, s. 123). Według cytowanego powyżej Raportu wdrażanie polityki i programów na rzecz osób z niepełnosprawnością intelektualną utrudnia jeszcze bardzo silny podział kompetencji między poszczególnymi ministerstwami. Taka sytuacja zmusza często osoby $\mathrm{z}$ niepełnosprawnością intelektualną do ubiegania się o pomoc $\mathrm{w}$ różnych instytucjach (tamże, s. 124). W raporcie uchwycona została również kwestia miejsca organizacji pozarządowych we wsparciu osoby niepełnosprawnej intelektualnie i jej rodziny, ale również organizacji jako partnera $\mathrm{w}$ działaniach prowadzonych $\mathrm{w}$ danym środowisku $\mathrm{w}$ ramach realizowania lokalnej polityki społecznej na rzecz tej grupy osób.

Ważny to partner, bo często z inicjatywy właśnie organizacji pozarządowych możliwe jest zabezpieczenie we wsparcie konkretnych grup osób niezauważalnych często na poziomie centralnym (dobrym przykładem są działania dotyczące mieszkalnictwa czy też zatrudnienia wspomaganego). Według przytaczanego raportu: „Wiele form wsparcia dla osób z niepełnosprawnością intelektualną istnieje obecnie częściowo dzięki znaczącym wysiłkom organizacji pozarządowych. Jednak, chociaż organizacje te przejęly na siebie wiele zadań związanych z rehabilitacją i edukacją osób z niepełnosprawnością intelektualną, rząd i samorządy lokalne nie traktują ich jak równoprawnych partnerów. Dla poprawy współpracy i poprawy jakości usług dostępnych dla osób z niepełnosprawnością intelektualną i ich rodzin rząd powinien przygotować i wdrożyć spójny oraz kompleksowy program wsparcia. Powinien on obejmować wszystkie okresy życia (od wczesnej interwencji do opieki nad osobami w podeszłym wieku) i zawierać wsparcie materialne, psychologiczne i społeczne" (tamże, s. 124).

Według I. Lindyberg cechy istniejącego systemu wsparcia w dorosłości osób z niepełnosprawnością intelektualną wskazują na "znaczny deficyt indywidualnego podejścia, skutkującego również miedzy innymi dominacją programu 
wsparcia/rehabilitacji nad osobą niepełnosprawną, pomijaniem indywidualnych celów i życzeń osoby wspomaganej oraz brakiem respektu dla autonomiczności i niezależności osób niepełnosprawnych. Wszystko to sankcjonuje w moim mniemaniu tradycyjny (medyczny) model niepełnosprawności, czyniący z osoby niepełnosprawnej przedmiot (obiekt) działań naprawczych" (2009, s. 21).

W odniesieniu do współczesnego paradygmatu wspierania dorosłych osób z niepełnosprawnością intelektualną, zdaniem M. Anasz, K. Mrugalskiej, J. Wojtyńskiej oraz M. Ferenc, w nowoczesnym podejściu do niepełnosprawności zwraca się uwagę na to, że:

- „osobie z niepełnosprawnością przysługują dokładnie te same prawa i wolności co każdej jednostce ludzkiej, zaś dyskryminacja jakiejkolwiek osoby ze względu na jej niepełnosprawność jest wykroczeniem przeciwko godności i wartości człowieka;

- na potencjał, talenty i możliwości osób z niepełnosprawnością oraz ich wiedzę, umiejętności i doświadczenie, które powinny być wykorzystywane dla dobra tych osób i całego społeczeństwa;

- na fakt, że uszkodzenia ciała często odgrywają mniejszą rolę w wykluczaniu osób niepełnosprawnych, niż bariery związane z organizacją i funkcjonowaniem społeczeństwa; liczne bariery środowiskowe oraz mentalne, będące przyczynami dyskryminacji osób niepełnosprawnych powinny być identyfikowane i ograniczane poprzez przebudowę infrastruktury środowiskowej, struktury instytucjonalnej, przepisów prawnych i świadomości społecznej (tj. systemów wartości i postaw społecznych);

- rozwiązywanie problemu niepełnosprawności polega na racjonalnym dostosowaniu fizycznego i społecznego środowiska, w którym żyją osoby z niepełnosprawnością do ich potrzeb, oczekiwań i możliwości;

- odmowa racjonalnego dostosowania środowiska do szczególnych potrzeb osób z niepełnosprawnością stanowi przejaw dyskryminacji;

- osoby niepełnosprawne mają prawo do autonomii oraz samodzielności, $w$ tym swobody dokonywania własnych wyborów;

- amodzielne życie $\mathrm{w}$ integracji społecznej powinno być zasadniczym celem udzielanej osobie niepełnosprawnej pomocy, rehabilitacji i wsparcia;

- konieczne jest stałe wspieranie osób niepełnosprawnych w ich zmaganiach z barierami fizycznymi i społecznymi, które utrudniają lub uniemożliwiają im wykonywanie codziennych czynności, korzystanie z praw, ale także podejmowanie obowiązków oraz pełne uczestnictwo w życiu społecznym" (2012-2014, s. 26).

Powyższe wyznaczniki współczesnego podejścia do wsparcia tej grupy osób znalazły się w publikacji podsumowującej stworzenie stargardzkiego modelu lokalnego systemu rehabilitacji i wsparcia społeczno-zawodowego osób z niepełno- 
sprawnością intelektualną i stanowily niewątpliwie w praktyce przesłanki do działań podejmowanych na rzecz tej grupy osób w danym środowisku.

A. Firkowska-Mankiewicz, nakreślając tło zmian w podejściu do osób z niepełnosprawnością intelektualną (w kontekście ich całożyciowego wsparcia), łączy owe korzystne zmiany $\mathrm{w}$ realizowanym modelem wsparcia obywatelskiego. Autorka przytacza następujące kluczowe elementy tego modelu:

„a) pełne uczestnictwo w życiu rodzinnym i w życiu społeczności - miejscem, w którym osoby niepełnosprawne mają prawo żyć jest społeczność i środowisko lokalne, a nie jakieś oboczne formy życia społecznego; podobnie jest z rodziną - człowiek ma prawo w niej żyć, a nie być z niej wyrywany i przenoszony do wyspecjalizowanych placówek;

b) więzi międzyludzkie - bycie częścią społeczności oznacza, że jednostka ma trwałe związki z innymi ludźmi, nie tylko z tymi, którzy są za to opłacani; naturalne systemy społecznego wsparcia nie są dostępne osobom żyjącym w specjalnych placówkach; ważnym aspektem jest fizyczna integracja ze środowiskiem - np. zamieszkiwanie w normalnym mieszkaniu w środowisku lokalnym;

c) funkcjonalne i zindywidualizowane programy - programowanie funkcjonalne koncentruje się na rozwijaniu sprawności, które są potrzebne jednostce w jej konkretnej sytuacji życiowej; funkcjonalne programowanie nie lekceważy potrzeby uczenia się, ale ocenia potrzebę zdobycia danej sprawności pod kątem tego, czy umożliwi ona jednostce zaistnienie w środowisku i wpłynie na lepszą jej integrację;

d) elastyczne i zindywidualizowane formy wsparcia - ich istotą jest umożliwienie osobom niepełnosprawnym niezależności, dokonywania własnych wyborów oraz kontroli nad własnym życiem" (2012, s. 45).

Przyglądając się sytuacji osób z głębszą niepełnosprawnością intelektualną w kontekście powyższych postulatów stanowiących sedno modelu obywatelskiego zwrócić należy uwagę nie tylko na pewną ideologię (sposób widzenia tej grupy osób), ale przede wszystkim na uwikłanie instytucjonalne i rozwiązania organizacyjne umożliwiające (lub nie) tej grupie osób niezależne i samodzielne (na miarę możliwości) życie.

Na przestrzeni ostatnich dwudziestu kilku lat wiele zmieniło się w myśleniu o wsparciu osób z niepełnosprawnością. Dobrze to ujmuje I. Wóycicka, opisując ten nowy paradygmat polityki społecznej wobec tej grupy osób. To nowe spojrzenie według autorki charakteryzuje się przede wszystkim odejściem od formalnej równości do równego traktowania. To myślenie o przejściu od równości formalnej do równości faktycznej (czyli równego traktowania) w prawie oznacza, że prawo musi uwzględniać różnice, które istnieją pomiędzy obywatelami, w tym również grupami osób niepełnosprawnych. W tym aspekcie nieuwzględnienie tych 
różnic powoduje, że równość formalna przekształca się niestety w faktyczną nierówność.

Drugą zmianą składająca się na współczesny paradygmat polityki społecznej wobec osób z niepełnosprawnością jest niewątpliwie przejście od jednorodności do różnorodności zgodnie z przekonaniem, iż każdy jest inny i ma różne potrzeby oraz możliwości. Zdaniem I. Wóycickiej dostrzeżenie tej różnorodności prowadzi do uchwycenia różnych ograniczeń i różnic w możliwościach funkcjonowania osoby niepełnosprawnej w różnych sferach życia społecznego i zawodowego. Jak twierdzi autorka: „każda dysfunkcja wymaga osobnego podejścia, namysłu, często też osobnego prawa i poszukania rozwiązań usuwających bariery w funkcjonowaniu osoby niepełnosprawnej. Tak jest z każdą dysfunkcją i z każdym stopniem dysfunkcji. Prawo musi odpowiadać na te różnorodne ograniczenia i potrzeby obywateli. I to jest istotne przesłanie polityki społecznej, a w przypadku osób niepełnosprawnych jest to przesłanie polityki wobec osób niepełnosprawnych" (2012. s. 7-8).

Trzecią, osiową zmianą składającą się na współczesny paradygmat polityki społecznej wobec osób z niepełnosprawnością jest przejście od opieki do wsparcia czy też od opieki do pomocy. I jak ujmuje to autorka: „to jest zmiana podejścia, która musi się wyrażać również praktyką., po to właśnie usuwamy bariery, żeby osoby niepełnosprawne mogły uczestniczyć w życiu społecznym w sposób pełny. I to jest droga do emancypacji osób niepełnosprawnych" $(2012$, s. 8).

T. Żółkowska podkreśla, iż w przypadku osób z głębszą niepełnosprawnością intelektualną społeczeństwo "nie radzi sobie z rozwijaniem odpowiednich umiejętności będących podstawą optymalizacji ich losu" (2012, s. 76). Według autorki można zaobserwować nie tylko brak odpowiednich działań na rzecz wspomagania tej grupy osób, ale i rozwijania u nich umiejętności życia w społeczeństwie czy wręcz podejmowania działań utrudniających realizację przez nich wybranych potrzeb czy ograniczających ich aktywność.

Istotną kwestią jest tu też to, że: „podstawą dobrze funkcjonującego sytemu wspomagania rozwoju powinno być dokładne określenie oczekiwań podmiotów i społeczeństwa co do obszaru, jakości usług, a następnie warunków, w jakich usługi na rzecz wspomagania będą prowadzone. Ważne jest też określenie zasobów podmiotów, jak i indywidualnych i społecznych kryteriów oceny realizacji usług na rzecz wspomagania rozwoju osoby z niepełnosprawnością. Skuteczne wspomaganie dające możliwość osobie z niepełnosprawnością intelektualną w stopniu głębszym dobrego niezależnego życia powinno być prowadzone od wczesnego okresu rozwoju do okresu starości. Niepełnosprawna intelektualnie osoba powinna być przygotowana do samodzielności, niezależności, kierowania swoim życiem. Musi w tym celu uzyskać odpowiednią wiedzę i umiejętności. 
Musi mieć stworzone warunki dla doświadczania w stawaniu się członkiem społeczeństwa" (2012, s. 82-83).

Taki sposób widzenia systemowego wsparcia dla osób z niepełnosprawnością intelektualną zawiera się $\mathrm{w}$ zasadzie $\mathrm{w}$ modelu indywidualnego uczestnictwa. $\mathrm{W}$ takie koncepcji indywidualnego wspierania kluczowymi elementami są:

- „pełne uczestnictwo w życiu rodzinnym i w życiu społeczności,

- więzi międzyludzkie,

- funkcjonalne i zindywidualizowane programy,

- elastyczne i zindywidualizowane formy wsparcia”, (Raport, 2008. s. 10-11).

Zwrócić uwagę należy na fakt, iż dorosła osoba z głębszą niepełnosprawnością intelektualną potrzebuje wsparcia w wielu wymiarach swojego życia oraz, że to pełne uczestnictwo jest zawsze uczestnictwem „na miarę” możliwości danej osoby. Uwzględnienie międzyludzkich relacji jako ważnego wymiaru, od jakiego zależy jakość życia osób wspomaganych, musi skutkować szukaniem rozwiązań, $\mathrm{w}$ których osoba z niepełnosprawnością intelektualną może pełnić różne role społeczne (adekwatne do swoich możliwości) i dzięki pełnieniu których zaspokajane są/będą potrzeby i pragnienia tych osób. W zasadzie dążenie do wcielania w życie modelu indywidualnego wspierania ma swoje poważne skutki dotyczące relacji w triadzie: osoba wspomagana - rodzina - profesjonaliści: „implikacje te są bardzo poważne i dotyczą przede wszystkim zmian w relacji władzy między dotychczasowymi «dostarczycielami» służb i usług, a osobą niepełnosprawną i jej rodziną. Osoba ta staje się bowiem podmiotem, nie zaś - jak dotąd - przedmiotem zabiegów, a sukcesem całego przedsięwzięcia jest poprawa jakości jej życia, a nie podporządkowanie odgórnemu programowi. Oznacza to zniesienie hegemonii, czyli panowania profesjonalistów, organizatorów służb i usług oraz personelu nad życiem osób niepełnosprawnych intelektualnie. I to jest właśnie powód, dla którego zmiany te odbierane są przez wielu z nich jako zagrażające ich dotychczasowej pozycji. Tymczasem trzeba zdawać sobie sprawę z tego, że zmiana postaw w kierunku bardziej otwartych, elastycznych i odbiurokratyzowanych jest procesem, od którego nie ma odwrotu". (Raport podsumowujący działalność Centrum Doradztwa Zawodowego i Wspierania Osób Niepełnosprawnych Intelektualnie, 2018, s. 12).

\section{Refleksje na temat budowania lokalnego systemu wsparcia dorosłych osób z niepełnosprawnością intelektualną w Gdańsku}

Jako przykład możliwości budowania lokalnego systemu wsparcia dorosłych osób z niepełnosprawnością (ze szczególnym uwzględnieniem osób niepełnosprawnych intelektualnie) postaramy się przybliżyć działania zainicjowane przez 
Miejski Ośrodek Pomocy Rodzinie w Gdańsku. Wydają się być one ciekawą i inspirującą praktyką zmieniającą rzeczywistość. Pierwszym etapem pracy w środowisku stało się zaproszenie podmiotów funkcjonujących $w$ tym środowisku, a świadczących usługi dla dorosłych osób z niepełnosprawnością. Już podczas pierwszych spotkań objawiły się dwie szczególne grupy klientów: były to osoby z głębszą i głęboką niepełnosprawnością intelektualną oraz osoby ze spektrum autyzmu. To o ich szczególnych potrzebach, o trudnościach i wyzwaniach związanych $\mathrm{z}$ ich wsparciem $\mathrm{w}$ dorosłości wielokrotnie dyskutowano. $\mathrm{W}$ zasadzie wszyscy przedstawiciele poszczególnych placówek byli przekonani od samego początku o ważności i potrzebie tego typu działań. Sam proces uzgadniania i określania braków i zasobów trwał kilka miesięcy. Istotną kwestią podjętą na samym początku było opracowanie kwestionariusza osoby nisko funkcjonującej. Chodziło o "namierzenie” w systemie takich osób. W ustalaniu zakresów, jakie powinny znaleźć się $\mathrm{w}$ takim kwestionariuszu, wzięli udział przedstawiciele wszystkich placówek wsparcia dla osób niepełnosprawnych w Gdańsku (Środowiskowych Domów Samopomocy, Warsztatów Terapii Zajęciowej, Domu Pomocy Społecznej, mieszkalnictwa wspieranego oraz zatrudnienia wspomaganego). W licznych dyskusjach podczas wielu spotkań szczególną uwagę poświęcono funkcjonującym w lokalnym środowisku Warsztatom Terapii Zajęciowej i Środowiskowym Domom Samopomocy.

Według Elżbiety Zakrzewskiej-Manterys „w funkcjonującym obecnie systemie wsparcia dla osób niepełnosprawnych intelektualnie warsztaty terapii zajęciowej traktowane są jako przywilej czy jako przepustka do przyszłego zatrudnienia. Osoby nierokujące, że znajdą swoje miejsce w systemie zatrudnienia (najlepiej na otwartym rynku pracy), kierowane są do instytucji opiekuńczych (środowiskowe domy samopomocy, ośrodki dziennego pobytu), gdzie z góry skazane są „na straty", gdyż nie jest oferowana im żadna forma rehabilitacji zawodowej. Traktowanie warsztatów terapii zajęciowej jako «kuźni kadr» dla Zakładów Aktywizacji Zawodowej i instytucji otwartego rynku pracy przynosi korzyść tylko elitarnej grupce wysoko funkcjonujących osób niepełnosprawnych intelektualnie w stopniu umiarkowanym (najczęściej jest to pogranicze upośledzenia umiarkowanego i lekkiego), które prawdopodobnie i tak znalazłyby zatrudnienie, nawet nie uczestnicząc w rehabilitacji zawodowej w warsztatach terapii zajęciowej. Dla zdecydowanej większości pozostałych osób z tej grupy możliwość przyszłego zatrudnienia to mrzonka, traktowana z przymrużeniem oka" (2014, s. 32).

W ocenie funkcjonowania osób, które wsparcie znalazły lub znajdą w WTZ lub w ŚDS jako priorytetowe do oceny poziomu funkcjonowania i potrzeb tych osób, wybrano następujące zakresy:

- niekontrolowane opuszczanie miejsca pobytu,

- poważna agresja wobec innych osób i/lub autoagresja 
- umiejętność funkcjonowania w grupie,

- nadwrażliwość na bodźce zmysłowe uniemożliwiające lub utrudniające przebywanie w dużej grupie,

- komunikacja niewerbalna i werbalna,

- motoryka duża,

- motoryka mała,

- samodzielność w zaspakajaniu podstawowych potrzeb - jedzenie,

- samodzielność w zaspakajaniu podstawowych potrzeb - potrzeby fizjologiczne,

- samodzielność w zaspakajaniu podstawowych potrzeb - higiena,

- możliwość pozostawania bez opieki innej osoby w miejscu pobytu,

- stosowanie niezbędnych leków i środków pielęgnacyjnych, których osoba niepełnosprawna nie jest $\mathrm{w}$ stanie samodzielnie używać.

Powyższe zakresy znalazły się $\mathrm{w}$ opracowanym kwestionariuszu będącym tak naprawdę skalą ocen, bowiem każdemu z zakresów przypisano pewne zachowania czy też umiejętności w skali 0/5/10 punktów, przy czym „10” oznacza zawsze najniższe możliwości czy też najbardziej nasilone problemy. Aby zorientować się jaka jest skala problemu osób nisko funkcjonujących będących już w placówkach wsparcia poproszono o przeprowadzenie oceny funkcjonowania uczestników, podopiecznych w każdej z placówek. Wszystkie wyniki i dane osób ocenionych jako nisko funkcjonujące zostały dostarczone do Miejskiego Ośrodka Pomocy Rodzinie. Tym sposobem można było łatwo zorientować się jakie osoby korzystają z danego rodzaju wsparcia i czy jest ono adekwatne do możliwości i potrzeb osoby. Oczywiście już ta pierwsza ocena potwierdziła, iż nie zawsze to wsparcie jest adekwatne. Przykładem mogą być osoby nisko funkcjonujące korzystające ze wsparcia w Warsztatach Terapii Zajęciowej czy też brak takich osób lub pojedyncze przypadki korzystania przez takie osoby ze wsparcia w Środowiskowych Domach Samopomocy. Ewidentnie taka rzeczywistość jest tworzeniem warunków do terapeutycznej fikcji lub też wiąże się z ograniczaniem możliwości wspierania tych, którzy potrzebują adekwatnego wsparcia. Większość osób, które nie uzyskiwały odpowiedniego wsparcia, to oczywiście osoby z głębszą niepełnosprawnością intelektualną.

Według raportu końcowego z badania sytuacji Warsztatów Terapii Zajęciowej z 2014 roku, oceniając specyfikę procesu rehabilitacji społecznej i zawodowej oraz jakość działań prowadzonych przez WTZ, „nie można jednak pomijać ani kontekstu historycznego działalności tych placówek, ani szeroko rozumianych uwarunkowań systemowych zarówno na poziomie centralnym, jak i lokalnym, a przede wszystkim potrzeb uczestników tych placówek" (Raport, 2014, s. 221). Jednocześnie warty podkreślenia jest fakt, że zebrane w Raporcie dane ilościowe i jakościowe dotyczące kondycji tego typu placówek i ich „efektywności” do- 
tyczącej wspierania w dorosłości adekwatnego do potrzeb i możliwości danej osoby, upoważniają do wyciągnięcia następujących istotnych wniosków:

- „Warsztaty terapii zajęciowej wyprzedzając inne formy wsparcia, takie jak np. środowiskowe domy samopomocy, są niejako pionierskimi instytucjami, które powstawały w odpowiedzi na najbardziej palące potrzeby związane ze wsparciem osób niepełnosprawnych, często skupiające się przede wszystkim na zapewnieniu im warunków "godnego" życia. Dziś świadomość problemów tej grupy jest dużo większa, jak i większe są możliwości wszechstronnego wsparcia. Inaczej wobec osób niepełnosprawnych formułowane są też cele polityk publicznych, skupiając się głównie na kwestii włączenia i równej partycypacji, w tym również w obszarze zawodowym. Nie oznacza to jednak, iż podstawowe problemy tej grupy zniknęły, a zadania realizowane przez warsztaty terapii zajęciowej straciły na ważności. Wręcz przeciwnie.

- Dziś warsztaty terapii zajęciowej są jedną z wielu dostępnych form oparcia społecznego dla osób niepełnosprawnych. Funkcjonujące w Polsce rozwiązania w zakresie programów oparcia społecznego w swoim zamyśle i celach umożliwiają prowadzenie skutecznych działań mających na celu włączenie społeczne osób niepełnosprawnych. Analizując system wsparcia dostrzeżono duży potencjał instytucjonalny. Obecne warunki prawno-strukturalne umożliwiają tworzenie i funkcjonowanie zróżnicowanych form wsparcia osób niepełnosprawnych, począwszy od specjalistycznego wsparcia medycznego poprzez wsparcie środowiskowe aż po działania $\mathrm{w}$ zakresie rehabilitacji społecznej i zawodowej. Istniejące rozwiązania systemowe bez wątpienia dają możliwość budowania i wdrażania efektywnych długofalowych strategii wsparcia społecznego dla osób niepełnosprawnych, których finalnym efektem powinno być wejście lub powrót na otwarty rynek pracy. Warsztaty terapii zajęciowej są ważnym, ale jedynie ogniwem całego systemu. Konsekwentnie nie można ich oceniać w oderwaniu od sprawności tego systemu. Przedmiotem analizy i oceny powinno być funkcjonowanie całego systemu - potencjału i możliwości innych instytucji, istniejących mechanizmów współpracy i rozwoju, a nade wszystko zewnętrznych uwarunkowań o charakterze systemowym/legislacyjnym oraz społecznym.

- Wreszcie należy wziąć pod uwagę małą uniwersalność warsztatów terapii zajęciowej w rozumieniu grupy ich beneficjentów. Warsztaty terapii zajęciowej są placówką skupiającą głównie osoby niepełnosprawne intelektualnie lub chorujące psychicznie, często o bardzo znacznym stopniu niepełnosprawności. Jest to bardzo specyficzna grupa, tymczasem przykłada się do niej takie same miary skuteczności, jak w procesie rehabilitacji innych grup osób niepełnosprawnych" (Raport, 2014, s. 221-222). 
W świetle powyższych wniosków istotnym punktem pracy nad lokalnym systemem wsparcia dorosłych osób z niepełnosprawnością w Gdańsku, było między innymi stworzenie zespołu opiniującego do spraw kierowania do Środowiskowych Domów Samopomocy dla osób z niepełnosprawnością intelektualną i Warsztatów Terapii Zajęciowej. I choć zarządzenie dyrektora Miejskiego Ośrodka Pomocy Rodzinie w Gdańsku umiejscawiające ten zespół w systemie weszło w życie dopiero 2.09.2016 r., to pilotaż tego typu rozwiązania zaczął się już w kwietniu $2015 \mathrm{r}$.

Już w działaniach pilotażowych ustalono, że w skład zespołu wchodzić będzie zawsze: przedstawiciel Działu do spraw Osób Niepełnosprawnych MOPR w Gdańsku, przedstawiciel podmiotu prowadzącego Środowiskowy Dom Samopomocy (rotacyjnie) oraz przedstawiciel podmiotu prowadzącego WTZ (rotacyjnie). Posiedzenia Zespołu od samego początku odbywały się nie rzadziej niż raz na miesiąc, chyba że nie było (nie ma) takiej potrzeby, co może mieć miejsce w momencie gdy brakuje kandydatów. Podczas posiedzenia Zespół dokonuje oceny funkcjonowania danej osoby na podstawie kwestionariusza, który wcześniej omówiono. Sama osoba starająca się o daną kwalifikację musi dostarczyć wypełniony formularz dotyczący ewentualnego uczestnictwa w WTZ lub ŚDS. W formularzu tym najistotniejszymi punktami jest krótka historia kandydata (dotychczasowa edukacja, uczestnictwo w placówkach wsparcia bądź innych formach wsparcia, zainteresowania kandydata) oraz oczekiwania kandydata (ze szczególnym uwzględnieniem rehabilitacji zawodowej). Aby umożliwić wybór typu placówki i form wsparcia samym osobom $\mathrm{z}$ niepełnosprawnością $\mathrm{w}$ formularzu znalazł się również punkt dotyczący deklaracji uczestnictwa w danej placówce (w tym miejscu prosi się kandydata o dokładne wskazanie placówki, podanie adresu).

Ustalono, że taki formularz składają również osoby, które korzystają ze wsparcia, ale chciałyby zmienić formę ze Środowiskowego Domu Samopomocy na Warsztat - lub odwrotnie. Istotną kwestią stało się $w$ takich przypadkach (zmiany placówki) wprowadzenie obowiązku dostarczenia przez daną placówkę pisemnej opinii dotyczącej kandydata oraz wypełnienia w placówce (i dostarczenia) formularza oceniającego poziom funkcjonowania kandydata.

Od pilotażu takiego rozwiązania, jakim jest zespół kwalifikujący do wydania zarządzenia, minęło kilka miesięcy, ale już pierwsze posiedzenia pokazały rzeczywistą potrzebę takiej wybranej drogi budowania lokalnego systemu wsparcia. I rzeczywiście uzasadnienie zarządzenia trafia w samo sedno tego rozwiązania: „Wydanie przedmiotowego zarządzenia ma na celu uściślenie zasad procesu wskazywania właściwej formy wsparcia dla osoby niepełnosprawnej oraz dokonywania zmian kwalifikacji, ze względu na jej osobiste predyspozycje. Przyczyni się to do usprawnienia procesu kwalifikowania osób do ŚDS dla osób z niepełno- 
sprawnością intelektualną i WTZ oraz dokonywania zmian kwalifikacji, przy zachowaniu obiektywizmu procedury kwalifikowania oraz zapewnienia prawidłowego nadzoru nad jej realizacją. Po uwagach kandydatów oraz organizacji pozarządowych, że dotychczasowa procedura wprowadzała $\mathrm{w}$ błąd, niebędąc etapem przyjęcia do placówek, zdecydowano o wprowadzeniu zmian".

Ważnym obszarem zmian, jakie wiązały się z tworzeniem nowego systemu wsparcia (ale też kreowaniem nowego, innego myślenia o tym wsparciu), stała się praca nad ujednoliceniem dokumentacji w poszczególnych typach placówek funkcjonujących w środowisku. Przyglądając się tej pracy „od środka” i uczestnicząc w nich, można odnieść wrażenie, iż najtrudniejszym wyzwaniem tej kilkumiesięcznej pracy było wynegocjowanie pewnego wspólnego sposobu myślenia o wsparciu w dorosłości, co przełożyło się w bezpośredni sposób na myślenie o dokumentacji. Pomimo licznych trudności w uzgadnianiu wspólnej wizji działań wspierających dorosłe osoby z niepełnosprawnością udało się ujednolicić dokumenty we wszystkich Warsztatach Terapii Zajęciowej. Tak naprawdę w tym ujednoliceniu zawiera się decyzja poszczególnych placówek świadczących usługi rehabilitacyjne dla tej grupy osób, o realizowaniu wspólnej wizji procesu rehabilitacji. Ważnym dokumentem stał się przede wszystkim indywidualny program Rehabilitacji - w jego bowiem konstrukcji zawiera się pewien sposób myślenia o dorosłych osobach z niepełnosprawnością. Uzgodnienie, iż na poziomie celu szczegółowego zawsze profesjonaliści odnosić się będą do zakładanych efektów (a więc operacjonalizować będą cele rehabilitacyjne), jest niewątpliwie wyjściem poza tradycyjny, „naprawczy” sposób myślenia o działaniach wspierających. Cel operacyjny jest tu bowiem celem pozytywnym i wyprowadzany jest ze sfery możliwości, a nie sfery braków.

\section{Zakończenie}

Budowanie lokalnego systemu wspierania dorosłych osób z niepełnosprawnością w Gdańsku nie zostało jeszcze zakończone. Praca nad budowaniem tego systemu będzie dalej kontynuowana, choć obecnie została nieco „przysłonięta” poszukiwaniem rozwiązań w szerszym środowisku. Wszystkie bowiem Warsztaty Terapii Zajęciowej w Gdańsku od maja 2016 r. przystą̧iły do Pomorskiego Klastra WTZ-ów. Klaster powstał w ramach projektu „Upleciemy SIEĆ - klaster pomorskich WTZ" realizowanego przez Caritas Archidiecezji Gdańskiej. Projekt trwać będzie do listopada 2017 r. Głównym celem projektu jest oczywiście zintegrowanie środowiska związanego z działalnością Warsztatów Terapii Zajęciowej wokół wspólnie podzielanych celów oraz stworzenie regionalnej reprezentacji przedsta- 
wicieli pomorskich WTZ. Działania te jednak mają zupełnie inny charakter i są „sformalizowane" w przestrzeni realizowanego projektu.

Specyficzne w opisywanych przez nas w niniejszym tekście działaniach skoncentrowanych na wykorzystaniu potencjału środowiska lokalnego $\mathrm{w}$ budowaniu/„uzdrowieniu” systemu wspierania w dorosłości osób z niepełnosprawnością (ze szczególnym uwzględnieniem wsparcia osób z głębszą niepełnosprawnością intelektualną) $\mathrm{w}$ formule instytucjonalnej jest to, że:

- wszystkie działania miały na pewnych etapach charakter nieformalny;

- praca zaangażowanych przedstawicieli poszczególnych placówek była pracą społeczną;

- warunkiem efektywnej pracy stała się otwartość pracowników miejskiego ośrodka pomocy rodzinie w Gdańsku, dokładniej Działu ds. osób niepełnosprawnych - to bowiem był proces zainicjowany przez pracowników tego działu;

- w początkowym etapie pracy kluczowe stało się poszukiwanie odpowiedzi na pytanie nie tylko o to jakie wyzwania i bariery we wspieraniu $\mathrm{w}$ dorosłości osób z niepełnosprawnością dostrzegane są przez osoby bezpośrednio tym wsparciem zajmujące się, ale też o to co w dotychczasowym systemie wspierania działa dobrze;

- istotnym elementem budowania systemu stało się stworzenie sposobu kwalifikowania dorosłych osób z niepełnosprawnością, adekwatnie do ich możliwości, ale też zgodnie $\mathrm{z}$ ich potrzebami czy też preferencjami;

- najtrudniejszym etapem pracy był etap ujednolicenia dokumentacji, czyli przyjęcia pewnych standardów $\mathrm{w}$ rehabilitacji. Tak naprawdę był to długotrwały proces uzgadniania znaczeń nadawanych wsparciu $\mathrm{w}$ dorosłości i działaniom rehabilitacyjnym adresowanym do osób z niepełnosprawnością. Ten proces przekładał się bowiem bezpośrednio na sposób rozumienia celów rehabilitacyjnych, postrzeganie indywidualnych programów rehabilitacji czy też przyjmowania kryteriów postępu w terapii osób wspomaganych.

$\mathrm{W}$ istocie to dopiero początek drogi w budowaniu pewnego wspólnego sposobu widzenia (pewnej ideologii) wsparcia w dorosłości osób z niepełnosprawnością w opisywanym środowisku. Osoba z umiarkowanym, znacznym czy głębokim stopniem niepełnosprawności intelektualnej to szczególny klient w systemie wsparcia. Dorosłość osób z niepełnosprawnością intelektualną wymaga wspierania w wielu zakresach, ale wszędzie tam, gdzie mamy do czynienia z uwikłaniem instytucjonalnym tej dorosłości, pojawia się potrzeba refleksji nad znaczeniami nadawanymi przez profesjonalistów wsparciu w tej dorosłości. W istocie taka refleksja i dobra wola ze strony organów nadzorujących pracę placówek świadczących usługi dla dorosłych osób z niepełnosprawnością może zmieniać rzeczywistość, nawet wówczas, gdy przez długi czas przybiera postać działań nieformalnych. 


\section{Bibliografia}

Anasz M., Mrugalska K., Wojtyńska J., Ferenc M.M. (2012-2014), Życie w integracji. Stargardzki model lokalnego systemu rehabilitacji i wsparcia społeczno-zawodowego osób z niepetnosprawnością intelektualną, Warszawa.

Bakiera L., Stelter Ż. (2010), Wspomaganie rozwoju osób niepetnosprawnych intelektualnie [w:] Diagnoza potrzeb i modele pomocy dla osób z ograniczeniami sprawności, red. A.I. Brzezińska, R. Kaczan, K. Smoczyńska, Warszawa.

Mirkowska-Mankiewicz A. (2012-2014), Integracja osób z niepetnosprawnościq intelektualna zagadnienia teoretyczne [w:] Życie w integracji. Stargardzki model lokalnego systemu rehabilitacji i wsparcia społeczno-zawodowego osób z niepetnosprawnościq intelektualnq, red. M. Anasz, K. Mrugalska, J. Wojdyńska, M.M. Ferenc, Warszawa.

Lindyberg I. (2009), Pytanie o specyfikę systemu instytucjonalnego wsparcia dorostych osób z niepetnosprawnościa [w:] Życie z niepetnosprawnościa. Trud dorastania i społecznej egzystencji, „Niepełnosprawność. Półrocznik Naukowy”, nr 2.

Szalast A. (2012), Rola ośrodków wsparcia dziennego we wspomaganiu funkcjonowania rodziny $z$ dorostym dzieckiem z niepetnosprawnościq intelektualna i/lub psychiczna, Wychowanie w Rodzinie, t. 6, Jelenia Góra.

Tylewska-Nowak B. (2011), Wypetnianie zadań rozwojowych przez osoby dorosłe z umiarkowang i znacznq niepetnosprawnościq intelektualna [w:] Dorośli z niepetnosprawnościq intelektualna w labiryntach codzienności Analiza badań - krytyka podejść - propozycje rozwiąań, red. B. Cytowska, Torun.

Urbański R. (1986), Refleksje nad etycznym paradygmatem andragogiki, „Oświata Dorosłych”, nr 9.

Wolska D. (2011), Wpływ prawidłowego przystosowania społecznego na jakość życia osób dorostych z niepetnosprawnością intelektualna [w:] Dorośli z niepetnosprawnościq intelektualna w labiryntach codzienności Analiza badań - krytyka podejść - propozycje rozwiązań, red. B. Cytowska, Torun.

Wóycicka I. (2012), Nowy paradygmat polityki społecznej wobec osób niepełnosprawnych [w:] Niepetnosprawność - nowe spojrzenie, materiały z międzynarodowej konferencji nt. „Węzłowe zagadnienia wdrażania Konwencji Narodów Zjednoczonych o prawach osób niepełnosprawnych oraz Europejskiej strategii w sprawie niepełnosprawności 2010-2020", Warszawa.

Zakrzewska-Manterys E. (2014), Rehabilitacja zawodowa osób niepetnosprawnych intelektualnie a rola WTZ [w:] Badanie sytuacji Warsztatów Terapii Zajęciowej. Raport końcowy z badania, Warszawa.

Zawiślak A. (2008), Problemy autonomii osób dorostych z niepetnosprawnościq intelektualną [w:] Nauki o edukacji, red. M. Karwowska, „Rocznik Naukowy Kujawsko-Pomorskiej Szkoły Wyższej w Bydgoszczy", nr 3, Bydgoszcz.

Żółkowska T. (2011), Wspomaganie rozwoju dorostych osób z niepetnosprawnościa intelektualną-refleksje pedagoga [w:] Dorośli z niepetnosprawnościa intelektualną w labiryntach codzienności Analiza badań - krytyka podejść - propozycje rozwiazań, red. B. Cytowska, Toruń.

Żyta A. (2011), Rodzice i rodzeństwo petnosprawne a planowanie przyszłości dorostych osób z niepetnosprawnościa intelektualną [w:] Dorośli z niepetnosprawnościa intelektualna w labiryntach 
codzienności Analiza badań - krytyka podejść - propozycje rozwiązań, red. B. Cytowska, Torun.

Żyta A. (2009), Dorosłość osób z niepetnosprawnościq intelektualna w województwie warmińskomazurskim. Ograniczenia i możliwości w świetle relacji społecznych [w:] Życie z niepetnosprawnością. Trud dorastania i społecznej egzystencji, „Niepełnosprawność. Półrocznik Naukowy", $\mathrm{nr} 2$.

Inne

Raport: „Sprawiedliwość, prawa i integracja osób Niepełnosprawnych Intelektualnie” dotyczący sytuacji w Polsce a zrealizowanego przez Inclusion Europe.

Raport: „Prawa osób z niepełnosprawnością intelektualna. Dostęp do edukacji i zatrudnienia", Wydawnictwo PSOUU, Warszawa 2006.

Raport podsumowujący działalność Centrum Doradztwa Zawodowego i Wspierania Osób Niepełnosprawnych Intelektualnie, Warszawa 2008.

Badanie sytuacji Warsztatów Terapii Zajęciowej. Raport końcowy z badania, Warszawa 2014. 